\title{
Effect of preventive and simultaneous inoculations of Bacillus amyloliquefaciens (Fukumoto) strains on conidial germination of Botrytis cinerea Pers.:Fr.
}

Ahlem Hamdache ${ }^{1}$, Mohammed Ezziyyani² \& Ahmed Lamarti

1 Department of Biology, Faculty of Sciences, Abdelmalek Essaâdi University, 2121, Tetuan, Morocco.

2 Department of Life Sciences, Polydisciplinary Faculty of Larache, Abdelmalek Essaâdi University, Morocco.

\section{Correspondence}

\section{A. Hamdache}

E-mail: hamdach_ahlem@yahoo.fr

Received: 4 January 2018

Accepted: 16 May 2018

Published on-line: 12 June 2018

\section{Resumen}

Efecto de inoculaciones preventivas y simultáneas de cepas de Bacillus amyloliquefaciens (Fukumoto) sobre la germinacion de conidios de Botrytis cinerea Pers.:Fr.

Botrytis cinerea es un patógeno fúngico necrotrófico de varias plantas distribuido en todo el mundo. En el presente estudio se analizó el efecto de nueve aislados bacterianos sobre la germinación de conidios de $B$. cinerea. Los aislados se identificaron como Bacillus amyloliquefaciens. Para evaluar la eficacia de los aislados, se realizaron confrontaciones duales tanto preventivas como simultáneas con los conidios de $B$. cinerea. Los resultados mostraron que cinco aislados fueron más eficaces cuando se coinocularon simultáneamente con el patógeno. Cuatro aislados fueron más eficaces cuando se inocularon previamente cuatro horas antes el patógeno. La cepa denominada B24, mostró una inhibición de $(84.04 \%)$ en concentraciones muy bajas $\left(3 \times 10^{3} \mathrm{UFC} / \mathrm{ml}\right)$ y la cepa RA9 fue la cepa menos eficaz.

Palabras clave: Bacterias antagónicas, inhibición, concentración.

\begin{abstract}
Botrytis cinerea is a necrotrophic fungal plant pathogen distributed worldwide. In the current study, the effect of nine bacterial isolates, on germination of $B$. cinerea conidia were studied. The nine isolates were identified as Bacillus amyloliquefaciens. The efficacy of isolates was tested, at different concentrations, in preventive and simultaneous inoculations with $B$. cinerea conidia. Results showed that five Bacillus isolates were more effective when co-inoculated simultaneously with the pathogen. Four isolates showed more efficacies when inoculated previously four hours before the pathogen. The isolate denominated B24 was the only that showed an important percent inhibition (84.04\%) at the lower concentration tested $\left(3 \times 10^{3} \mathrm{CFU} / \mathrm{ml}\right)$ and the isolate RA9 was the less effective strain.
\end{abstract}

Key words: Bacterial antagonists, inhibition, concentration. 


\section{Introduction}

Strawberry gray mold, caused by Botrytis cinerea (de Bary) Whetzel, is one of the most serious diseases that affect fruits, leaves, petioles, stems, and flowers in cold and wet weathers (Agrios 2005). In addition, conidial spores contaminated during harvest can cause serious storage rot, especially when fruits are wet (Braun \& Sutton 1987). In field, new infections usually occur by wind-dispersed conidia, which germinate on the plant surface and invade the tissue either through wounds or by direct penetration of cuticles and cell walls of epidermal cells (Holz et al. 2004). The chemical control and use of fungicides are the most effective way of preventing the occurrence of Botrytis disease (Rabosto et al. 2006). However, the use of chemicals is considered undesirable because of concerns over residues, their potential adverse effects on human health and the environment (Zhang et al. 2015) and the fast development of resistance to novel fungicides by fungi (Leroux 2004, Walker et al. 2013, Hahn 2014, Romanazzi \& Feliziani 2014). Therefore, the difficulty in controlling $B$. cinerea has led to researchers to find alternative methods, which include biological control (Sutton 1995). Biological control has been shown to be successful in many other crops (Saligkarias et al. 2002) and as effective as chemical control (Dik \& Elad 1999). However, the efficacy of biological control is occasionally inadequate and variability may be high. The mechanisms involved in biological control include, among others, induced resistance, competition for nutrients, and secretion of inhibitory compounds. Bacillus spp. have shown promise for controlling a wide range of fungi that cause decay, operating as an antagonist to plant pathogen growth through

A

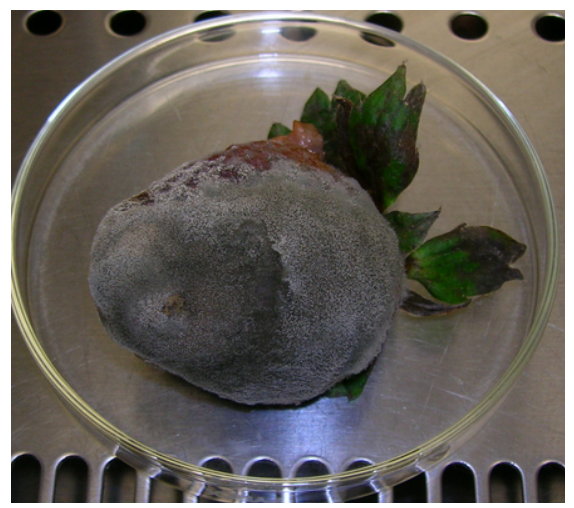

their production of antibiotics (iturin, surfactin, fengycin), enzymes that degrade fungal structural polymers (chitinase, $\beta-1,3$ glucanase), and antifungal volatiles (Leelasuphakul et al. 2006). Bacillus amyloliquefaciens has an antibacterial activity against Xanthomonas oryzae (Ishiyama 1922) Swings et al. (Wu et al. 2015) and antifungic activity against Penicillium digitatum (Pers.) Sacc., Magnaporthe grisea (T.T. Hebert) M.E. Barr (=Pyricularia grisea Sacc.) and Sclerotinia sclerotiorum (Lib.) de Bary (Ji et al. 2013), Fusarium verticillioides (Sacc.) Nirenberg and Aspergillus flavus Link (Etcheverry et al. 2009) and also against Pythium aphanidermatum (Edson) Fitzp. (Zouari et al. 2016). In the present study, the inhibition of conidial germination of $B$. cinerea was investigated to characterize potential bacterial biocontrol agents isolated from rhizospheric soil of strawberry plants. The effect of nine isolates of Bacillus amyloliquefaciens Priest et al., at different concentrations, was compared at two times of inoculations ( $\mathrm{T}=0 \mathrm{~h}$, as a simultaneous inoculation and $\mathrm{T}=4 \mathrm{~h}$ as a preventive inoculation).

\section{Materials and methods}

\section{Pathogenic fungi}

B. cinerea pers.; Fr. the causal agent of gray mold disease on strawberry fruits was kindly isolated from diseased strawberry fruits (Fig. 1A) from a field of Lokkous (Larache, north of Morocco). The isolate was purified, identified by macroscopic and microscopic observations using keys of determination (Samson et al. 1984, Botton et al. 1990), noted Bt7 and maintained on PDA (Potato Dextrose Agar) medium (Fig. 1B).

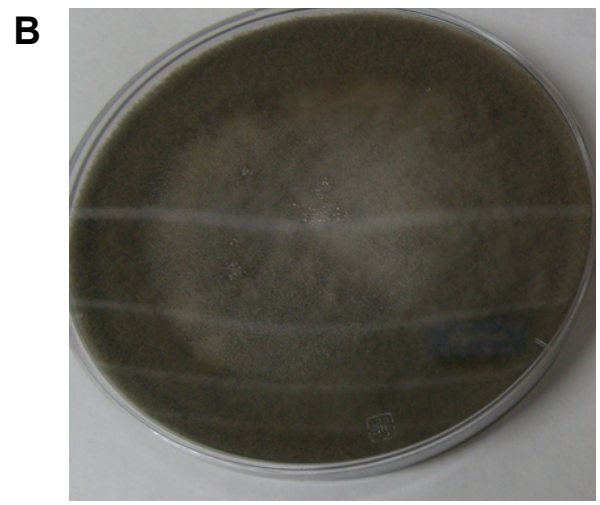

Figura 1. Podredumbre de la fresa causada por el aislado Botrys cinerea (Bt7) (A) y aspecto macroscópico del hongo en medio PDA (B). Figure 1. Botrys cinerea (Bt7) on diseased strawberry fruit (A) and on PDA medium (B). 
Conidia were harvested from 10- to 14-day-old cultures by agitating small pieces of agar bearing mycelia and conidia in a glass tube containing 4 $\mathrm{ml}$ of sterile distilled water. The suspension was filtered through cheesecloth, and the spore concentration was calibrated with a Malassez chamber and adjusted to $1 \times 10^{6}$ spores per $\mathrm{ml}$.

\section{Bacterial antagonists}

Nine bacterial isolates were selected, for their inhibitory effect against $B$. cinerea in vitro, from a mass selection (321 isolates) made by Hamdache (2012). These nine selected isolates were obtained from rhizospheric soil of healthy strawberry plants from the Loukkous zone in the north of Morocco. These included isolates I1, I2, I3, I18, B3, B24, B12, RA9 and RA12. Isolates were identified by amplification of the 16S rRNA gene by PCR as Bacillus sp. and showed $100 \%$ similarity with sequences of the $16 \mathrm{~S}$ rRNA gene of strains of $B$. amyloliquefaciens (Hamdache et al. 2012) contained in data bases (Table 1). For the preparation of the bacteria suspensions, isolates were streaked onto Petri dishes containing Luria Bertani medium and maintained at $28{ }^{\circ} \mathrm{C}$. After $24 \mathrm{~h}$ they were transferred to $50 \mathrm{~mL}$ fresh Luria Bertani liquid medium in a $250 \mathrm{~mL}$ Erlenmeyer flasks and maintained for $48 \mathrm{~h}$ under constant agitation $(125 \mathrm{rpm})$. For each antagonistic strain, and after $48 \mathrm{~h}$ cultivation, $5 \mathrm{ml}$ of medium was taken and cells were harvested by centrifugation at $4000 \mathrm{rpm}$ for $10 \mathrm{~min}$. The cells collected by centrifugation were washed twice with sterile distilled water by repeating the two centrifugation steps. Finally, cells were re-suspended in $5 \mathrm{ml}$ of sterile distilled water and adjusted to $3 \times 10^{8}$ colony-forming units $(\mathrm{CFU}) / \mathrm{ml}$, according to the scale of Mac Farland. Then, five decreasing concentrations were prepared: $3 \times 10^{7}, 3 \times 10^{6}, 3 \times 10^{5}$, $3 \times 10^{4}$ and $3 \times 10^{3} \mathrm{CFU} / \mathrm{ml}$.

The strains are deposited and available at the Faculty of Sciences-Tetuan, Abdelmalek Essaâdi University, Tetuan, Morocco.

\section{Effect of bacterial antagonists on conidial germination of $B$. cinerea}

To evaluate the effect of bacterial isolates on the conidia germination of $B$. cinerea, a volume of a $200 \mu \mathrm{l}$ B. cinerea conidia suspension adjusted to 106 conidia/ml was added to $200 \mu \mathrm{l}$ of bacterial suspensions of each of different concentrations $\left(3 \times 10^{7}, 3 \times 10^{6}, 3 \times 10^{5}, 3 \times 10^{4}\right.$ and $\left.3 \times 10^{3} \mathrm{CFU} / \mathrm{ml}\right)$. The two suspensions were mixed in tubes containing $5 \mathrm{ml}$ of sterile liquid medium PDB (Potato Dextrose Broth). The tubes were incubated 24 hours at $25^{\circ} \mathrm{C}$. Two applications time were compared; the first was simultaneous inoculation or co-inoculation $(\mathrm{T}=0 \mathrm{~h})$ of the two microorganisms (antagonist-pathogen) and the second was a preinoculation $(\mathrm{T}=4 \mathrm{~h})$ of the antagonist four hours before the addition of the pathogen. Each experiment using a single $B$. amyloliquefaciens isolate was run in triplicate. Results are expressed as the means of the percentage of inhibition of conidial germination of $B$. cinerea isolate in the presence of any of the strain of antagonistic bacteria. Percent inhibition was calculated using the following formula:

$\%$ inhibition $=[1-($ Conidial germination $/$ Control conidial germination) $] \times 100$

The data were statistically analyzed by applying a one-way ANOVA, for comparison of mean values, followed by Duncan's multiple range test at the 0.05 level of significance.

\begin{tabular}{|l|l|c|l|}
\hline $\begin{array}{c}\text { First name } \\
\text { of strain }\end{array}$ & $\begin{array}{c}\text { Code of strain after } \\
\text { identification }\end{array}$ & Percentage of similarity & Strain reference \\
\hline I1 & B. amyloliquefaciens Bc1 & $99,8 \%(1014 / 1016 \mathrm{pb})$ & LMG 22478 \\
\hline I2 & B. amyloliquefaciens Bc2 & $99,8 \%(1033 / 1035 \mathrm{pb})$ & CR-502 \\
\hline I3 & B. amyloliquefaciens Bc3 & $100,0 \%(1030 / 1030 \mathrm{pb})$ & CR-502 \\
\hline I18 & B. amyloliquefaciens Bc4 & $100,0 \%(1035 / 1035 \mathrm{pb})$ & CR-502 \\
\hline B3 & B. amyloliquefaciens Bc5 & $99,9 \%(1020 / 1022 \mathrm{pb})$ & LMG 22478 \\
\hline B12 & B. amyloliquefaciens Bc6 & $99,9 \%(1021 / 1022 \mathrm{pb})$ & LMG 22478 \\
\hline B24 & B. amyloliquefaciens Bc7 & $99,9 \%(1019 / 1020 \mathrm{pb})$ & LMG 22478 \\
\hline RA9 & B. amyloliquefaciens Bc8 & $99,9 \%(778 / 779 \mathrm{pb})$ & LMG 22478 \\
\hline RA12 & B. amyloliquefaciens Bc9 & $99,9 \%(1035 / 1036 \mathrm{pb})$ & CR-502 \\
\hline
\end{tabular}

Tabla 1. Identificación de cepas antagonistas de Bacillus amyloliquefaciens (Hamdache et al. 2012)

Table 1. Identification of antagonistic strains of Bacillus amyloliquefaciens (Hamdache et al. 2012) 


\section{Results and discussion}

In order to evaluate antagonistic activity of Bacillus strains against spore germination of $B$. cinerea, in vitro assays were performed. The effectiveness of the Bacillus isolates on the conidial germination of $B$. cinerea, in two different times of application of the bacterial suspension, $(\mathrm{T}=0$ hours and $\mathrm{T}=4$ hours) was compared. In the first case $(T=0 h)$, the two microorganisms, pathogen and antagonist, were co-inoculated at the same time. In the second case $(T=4 \mathrm{~h})$, the antagonist was pre-inoculated four hours before introducing the pathogen. The results showed that an important inhibition of conidial germination of $B$. cinerea was observed with all of isolates (Fig. 2). The bacterial antagonists I1, I2 and I3 were more efficient when co-inoculated with the pathogen. However, strains 118 and B24 showed more efficacy when inoculated four hours before the pathogen. B3 was very effective in both cases of inoculation at high concentration, but this efficacy decreased at low dose when it was co-inoculated with the pathogen. For the two isolates B12 and RA9, no difference was found between the two times of application ( $\mathrm{T}=0 \mathrm{~h}$ and $\mathrm{T}=4 \mathrm{~h}$ ) at low concentrations $\left(3 \times 10^{4}\right.$ and $\left.3 \times 10^{3} \mathrm{CFU} / \mathrm{ml}\right)$, but at high concentration simultaneous application was more effective. For all of the isolates and in the two cases of application of the antagonist the inhibition of conidial germination increased proportionally with the inoculum concentrations. The results showed that the highest percentage of inhibition $(100 \%)$ was observed at high concentration tested $\left(3 \times 10^{7} \mathrm{CFU} / \mathrm{ml}\right)$ and the lowest $(0.04 \%)$ (I2, $\mathrm{T}=4 \mathrm{~h})$ was at low concentration $\left(3 \times 10^{3} \mathrm{CFU} / \mathrm{ml}\right)$. At $3 \times 10^{5} \mathrm{CFU} / \mathrm{ml}$, the best inhibition percent of conidial germination by I18, I1, I2, I3, B24 and B3 isolates were 63.16, 77.79, 85.26, 89.93, 98.62 and $100 \%$ respectively. B24 and B3 showed the best inhibition and were more efficient than other antagonists when they were pre-inoculated, at low concentration with no statistically differences between the different concentrations tested $3 \times 10^{7}$, $3 \times 10^{6}, 3 \times 10^{5}$ and $3 \times 10^{4}$ showing inhibition percentages of 100, 98.95, 98.62 and $98.09 \%$ respectively for B24 and 100, 100, 100 and $96.33 \%$ respectively for B3. The B24 was the only isolate that showed an important inhibition percent $(84.04 \%)$ at the low concentration tested $3 \times 10^{3}$ CFU/ml. RA9 was the less effective, with percentage of inhibition lower than $40 \%$ at high concen- tration.

This study allowed us to determine the minimal inhibitory concentration of each isolate of $B$. amyloliquefaciens (Table 2) to inhibit conidial germination of $B$. cinerea. In biological control studies, a good biocontrol agent (BCA) must be effective at low concentration (Wisniewski \& Wilson 1992). Hence, we suggest that B. amyloliquefaciens B3 (Bc5) and B. amyloliquefaciens B24 (Bc7) can be considered as the best biological control agent with optimal inhibition of conidial germination of $B$. cinerea at low concentration.

\begin{tabular}{|c|c|c|}
\cline { 2 - 3 } \multicolumn{1}{c|}{} & \multicolumn{2}{c|}{ Time of application } \\
\hline $\begin{array}{c}\text { Antagonistic } \\
\text { isolates }\end{array}$ & $\begin{array}{c}\text { Simultaneous } \\
\text { (T= } \mathbf{~} \mathbf{h})\end{array}$ & $\begin{array}{c}\text { Preventive } \\
\text { (T = 4h) }\end{array}$ \\
\hline B3 & $3 \times 10^{5}$ & $3 \times 10^{4}$ \\
B24 & $3 \times 10^{7}$ & $3 \times 10^{4}$ \\
I2 & $3 \times 10^{7}$ & $3 \times 10^{7}$ \\
I3 & $3 \times 10^{6}$ & $3 \times 10^{7}$ \\
I18 & $3 \times 10^{6}$ & $3 \times 10^{6}$ \\
I1 & $3 \times 10^{6}$ & $3 \times 10^{7}$ \\
RA12 & $>3 \times 10^{7}$ & $>3 \times 10^{7}$ \\
B12 & $>3 \times 10^{7}$ & $>3 \times 10^{7}$ \\
RA9 & $>3 \times 10^{7}$ & $>3 \times 10^{7}$ \\
\hline
\end{tabular}

Tabla 2. Determinación de la concentración mínima inhibitoria de cepas de B. amyloliquefaciens sobre la germinación de conidios de $B$. cinérea.

Table 2. Minimal inhibitory concentration of $B$. amyloliquefaciens strains on conidial germination of $B$. cinerea.

B. amyloliquefaciens isolates used in this study were capable of reducing the germination of the pathogen $B$. cinerea.

These isolates differed by their mode of action and by their effectiveness according to the concentration and the time of application to the pathogen. In the dual confrontations of the antagonist against the pathogen in PDA medium (Fig. 3 ), the inhibition zone produced by $B$. amyloliquefaciens increased with time, an increase that was accompanied by the necrosis of the fungal mycelium that had developed so far (Hamdache et al. 2012). The first thing to be noticed was suppressed growth of $B$. cinerea with the suppression zone increasing as the growth of $B$. amyloliquefaciens increased. This was followed by a marked antibiosis and competition for space and nutrients, effect that was manifested by reduced pathogen mycelial growth. After seven days, B. amyloliquefaciens stopped the growth of $B$. cinerea colonies.

Bacillus species are well known for their ability to control plant diseases through various me- 

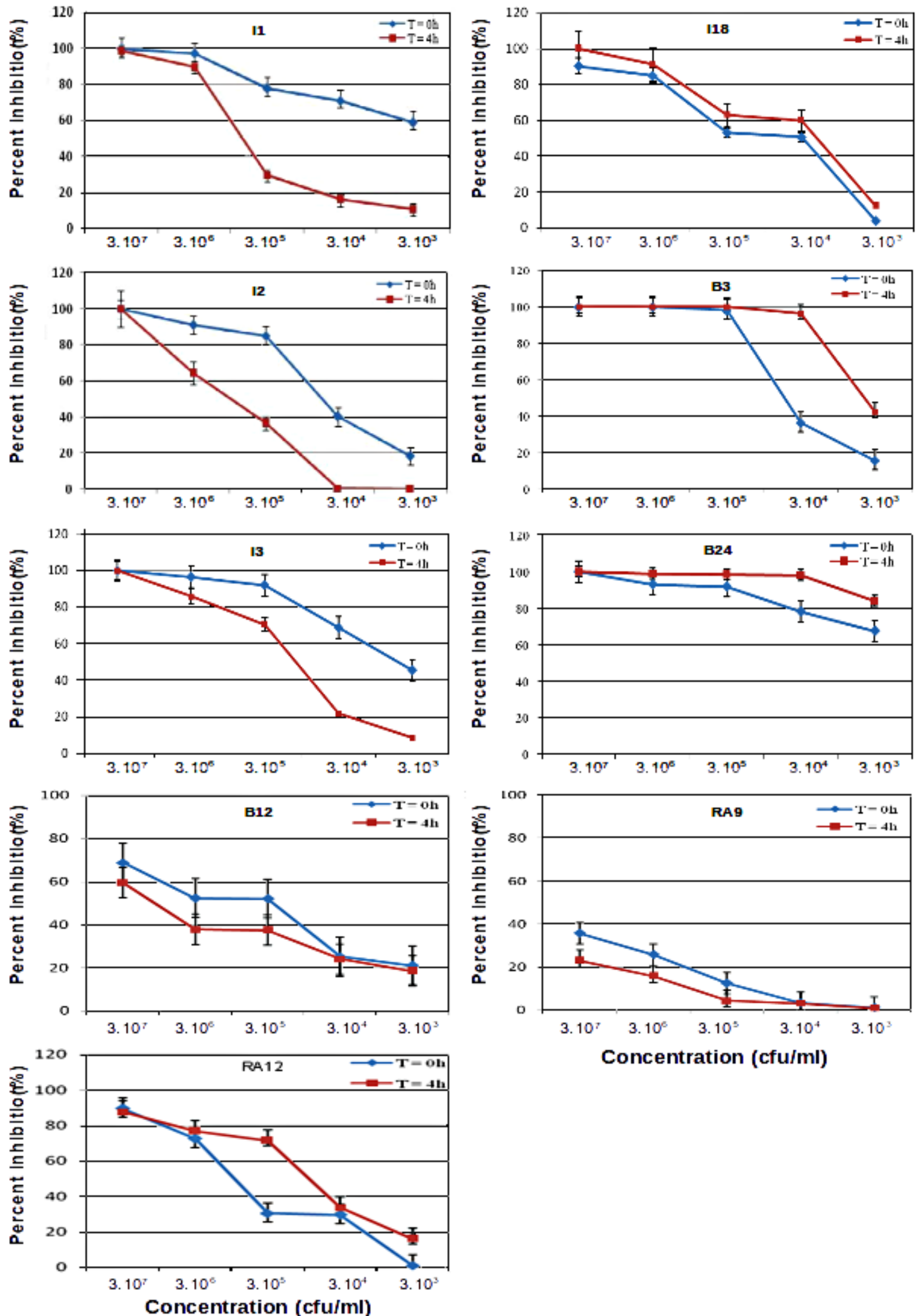

Figura 2. Efecto de la concentración y tiempo de inoculación de los aislados de B. amyloliquefaciens (I1, I2, I3, I18, B3, B24, B12, RA12 y RA9) sobre la germinación de conidios de B. cinerea.

Figure 2. Effect of concentration and time of inoculation of B. amyloliquefaciens isolates (I1, I2, I3, I18, B3, B24, B12, RA12 and RA9) on conidial germination of $B$. cinerea. 


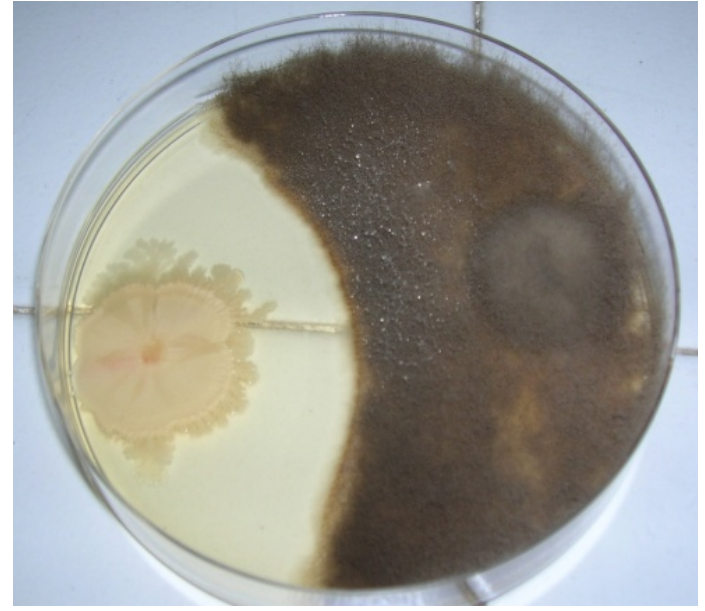

Figura 3: Inhibición del crecimiento vegetativo de $B$. cinérea por B. amyloliquefaciens B3 en el medio PDA.

Figure 3: Inhibition of the vegetative growth of $B$. cinerea by $B$. amyloliquefaciens B3 on PDA medium.

chanisms, including the production of secondary metabolites. Bacillus species are both taxonomically and metabolically diverse, and they exhibit enormous metabolic capabilities and versatile biochemistry through the production of structurally diverse bioactive chemical structures. Although Bacillus species mainly synthesize peptides, antibiotics belonging to other chemical classes are also produced by these microorganisms, and the determination of their chemical structure and the mechanism of their biological action are of fundamental and practical interest (Arguelles-Arias et al. 2009, Hamdache et al. 2013, Chowdhury et al. 2015). Although the isolates I1, I2 and I3 provide an inhibition of conidial germination when coinoculated simultaneously with the pathogen, the pre-inoculation of the $\mathrm{B} 3$ and $\mathrm{B} 24$ isolates gives a more important inhibition even at low concentration. The B24 was the only isolate that showed an importante inhibition percent $84.04 \%$ at the low concentration tested $\left(3 \times 10^{3} \mathrm{CFU} / \mathrm{ml}\right)$. Therefore, it could be selected as a good bacterial antagonist and used for further studies for controlling $B$. cinerea. B3 also gives a strong inhibition (100\%) at $3 \times 10^{5} \mathrm{CFU} / \mathrm{ml}$. As stated before, a good biocontrol agent (BCA) must be effective at low concentration (Wisniewski \& Wilson 1992). A combination of two compatible micro-organisms, Trichoderma harzianum Rifai and Streptomyces rochei Berger et al., both antagonistic to the pathogen Phytophthora capsicik Leonian, was used to control root rot in pepper where the optimal dose of the antagonists in the compound formulation was $3.5 \times 10^{8}$ spores $/ \mathrm{ml}$ of $T$. harzianum and $1.0 \times 10^{9}$
$\mathrm{CFU} / \mathrm{ml}$ of $S$. rochei (Ezziyyani et al. 2007). The strong inhibition of conidial germination during the pre-inoculation can be explained as an important bacterial colonization in the culture medium before the onset of the pathogen $B$. cinerea and consequently a competition for nutrients or a high secretion of antifungal metabolites. Several mechanisms can be used for controlling the pathogens, either directly inside the plant, by antibiosis against the pathogen (Sturz et al. 1998) and by the competition for nutrients (Mari et al. 1996), or indirectly by inducing a resistance response in the plant (M'Piga et al. 1997). B. cinerea is highly susceptible to competition because external nutrients are required for conidial germination (Elad 1996), germ tube growth and the successful completion of infection (Elad \& Stewart 2004). Nutrients are essential for the development of populations of epiphytic microorganisms, necrotroph pathogens, and nonpathogens alike. Competition for nutrients on plant surfaces is an important mechanism of biological control against pathogens that depend on external nutrition (Blakeman \& Brodie 1977, Elad \& Chet 1987, Morris \& Rouse 1985, Roberts 1990). For example, isolates of Rhodotorula glutinis (Fresen.) F.C. Harrison and Cryptococcus albidus (Saito) C.E. Skinner compete for nutrients with germinating conidia of B. cinerea (Elad et al. 1994, Elad 1996). Similarly, several bacterial isolates compete for glucose and asparagine with germinating oospores of $P$. aphanidermatum in the rhizosphere of various crops (Elad \& Chet 1987), and Pseudomonas fluorescens Migula suppresses Bipolaris maydis (Y. Nisik. \& C. Miyake) Shoemaker by competing with the pathogen for glucose (Mohamed \& Caunter 1995). It is well known that some Bacillus species may synthesize numerous antimicrobial or, more generally, bioactive compounds with well-established activity in vitro (Stein 2005, Hamdache et al. 2011). A Bacillus subtilis (Ehrenberg) Cohn strain was shown to reduce post-harvest infection of apples caused by $B$. cinerea, the causative agent of grey mold disease (Toure et al. 2004). Also it was shown to possess biocontrol activity against $X$. oryzae strains by producing the antibiotic compounds difficidin and bacilysin (Wu et al. 2015). Germination of $B$. cinerea conidia is inhibited by antifungal metabolites of Pseudomonas antimicrobica Attafuah and Bradbury. It was also shown that germination was almost completely inhibited 
when metabolites were added prior to germination (Walker et al. 2001). In this study we can conclude that B3 (Bc5) and B24 (Bc7) can be selected for their effectiveness at low concentration and might be applied preventively for best inhibition of conidial germination of $B$. cinerea.

\section{References}

Agrios GN. 2005. Plant Pathology. 5th édition, p : 922.

Arguelles-Arias A, Ongena M, Halimi B, Lara Y, Brans A, Joris B. \& Fickers P. 2009. Bacillus amyloliquefaciens GA1 as a source of potent antibiotics and other secondary metabolites for biocontrol of plant pathogens. Microbial Cell Factories 26: 8-63.

Blakeman JP \& Brodie I. 1977. Competition for nutrients between epiphytic microorganisms and germination of spores of plant pathogens on beet root leaves. Physiological Plant Pathology 10: 29-42.

Botton B, Breton A, Fèvre M, Gauthier S, Guy P, Larpent JP, Reymond P, Sanglier JJ, Vayssier Y \& Veau P. 1990. Moisissures utiles et nuisibles. Importance industrielle. 2e éd. revue et complétée. Paris, Milan, Barcelone: Masson, p. 512.

Braun PG \& Sutton JC. 1987. Inoculum sources of Botrytis cinerea in fruit rot of strawberries in Ontario. Canadian Journal of Plant Pathology 9: 1-5.

Chowdhury SP, Hartmann A, Gao XW \& Borriss R. 2015. Biocontrol mechanism by root-associated Bacillusamyloliquefaciens FZB42-areview. Frontiers in Microbiology 6: 780.

Dik AJ \& Elad Y. 1999. Comparison of antagonists of Botrytis cinerea in greenhouse-grown cucumber and tomato under different climatic conditions. European Journal of Plant Pathology 105: 123-137.

Elad Y \& Chet I. 1987. Possible role of competition for nutrients in biocontrol of Pythium damping-off by bacteria. Phytopathology 77: 190-195.

Elad Y \& Stewart A. 2004. Microbial control of Botrytis spp.. In: Botrytis: Biology, Pathology and Control. (Y Elad, B. Williamson, P. Tudzynski, N. Delen, eds.), Kluwer Academic Publishers, Dordrecht, Netherlands, 223-241.

Elad Y, Köhl J \& Fokkema NJ. 1994. Control of infection and sporulation of Botrytis cinerea on bean and tomato by saprophytic yeasts. Phytopathology 84 1193-1199.

Elad Y. 1996. Mechanisms involved in the biological control of Botrytis cinerea incited diseases. European Journal of Plant Pathology 102: 719-732.

Etcheverry M, Scandolara A, Nesci A, Vilas Boas Ribeiro MS, Pereira P \& Battilani P. 2009. Biological interactions to select biocontrol agents against toxigenic strains of Aspergillus flavus and Fusarium verticillioides from maize. Mycopathologia 167(5): 287295.

Ezziyyani M, Requena ME, Egea-Gilabert C \& Candela ME. 2007. Biological Control of Phytophthora Root Rot of Pepper Using Trichoderma harzianum and Streptomyces rochei in Combination. Journal of Phy- topathology 155 : 342-349.

Hahn M. 2014. The rising threat of fungicide resistance in plant pathogenic fungi: Botrytis as a case study. Journal of Chemical Biology 7: 133-141.

Hamdache A, Ezziyyani M, Badoc A \& Lamarti A. 2012. Effect of $\mathrm{pH}$, Temperature and Water Activity on the inhibition of Botrytis cinerea by Bacillus amyloliquefaciens isolates. African Journal of Biotechnology 11 (9) : 2210-2217.

Hamdache A, Lamarti A, Aleu J \& Collado IG. 2011. Non-peptide Metabolites from the Genus Bacillus. Journal of Natural Product 74 (4) : 893-899.

Hamdache A, R. Azarken, Lamarti A, Aleu J \& Collado IG. 2013. Comparative genome analysis of Bacillus spp. and its relationship with bioactive nonribosomal peptide production. Phytochemistry12: 685-716.

Holz G, Coertze S \& Williamson B. 2004. The ecology of Botrytis on plant surfaces, in Elad Y, Williamson B, Tudzynski P, Delen N, editors. (ed), Botrytis: biology, pathology and control. Kluwer Academic Publishers, Dordrecht, Netherlands, pp. 9-27.

Ji SH, Paul NC, Deng JX, Kim YS, Yun B-S \& Yu SH. 2013. Biocontrol Activity of Bacillus amyloliquefaciens CNU114001 against Fungal Plant Diseases. Mycobiology 41(4): 234-242.

Leelasuphakul W, Sivanunsakul P \& Phongpaichit S. 2006. Purification, characterization and synergistic activity of $\beta-1,3$-glucanase and antibiotic extract from an antagonistic Bacillus subtilis NSRS 89-24 against rice blast and sheath blight pathogens. Enzyme and Microbial Technology 38: 990-997.

Leroux P. 2004. Chemical control of Botrytis and its resistance to chemical fungicides. In: Botrytis: Biology, Pathology and Control. (Y. Elad, B. Williamson, P. Tudzynski, N. Delen, ed.), Kluwer Academic Publishers, Dordrecht, Netherlands, pp. 195-222.

M'piga $P$, Bélanger RR, Paulitz TC \& Benhamou N. 1997. Increased resistance to Fusarium oxysporum f. sp. radicis-lycopersici in tomato plants treated with the endophytic bacterium Pseudomonas fluorescens strain 63-28. Physiological and Molecular Plant Pathology 50: 301-320.

Mari M, Guizzardi M \& Pratella GC. 1996. Biological control of gray mold in pears by antagonistic bacteria. Biological Control 7: 30-37.

Mohamed S \& Caunter IG. 1995. Isolation and characterization of Pseudomonas fluorescens strain suppressive to Bipolaris maydis. Journal of Phytopathology 143: 111-114.

Morris CE \& Rouse DI. 1985. Role of nutrients in regulating epiphytic bacterial populations. Biological Control on the Phylloplane. C. E. Windels and E. Lindow, eds. The American Phytopathological Society, St. Paul, MN, pp. 63-82.

Rabosto X, Carrau M, Paz A, Boido E, Dellacassa E, Carrau FM. 2006. Grapes and vineyard soils as sources of microorganisms for biological control of Botrytis cinerea. American Journal Enology and Viticulture 57: 332-338.

Roberts RG. 1990. Postharvest biological control of gray mold of apple by Cryptococcus laurentii. Phytopathology 80: 526-530. 
Romanazzi G \& Feliziani E. 2014. Botrytis cinerea. In: Postharvest Decay: Control Strategies (S. BautistaBaños, ed.), Elsevier, London, 131-146.

Saligkarias ID, Gravanis FT and Eptona HAS. 2002. Biological control of Botrytis cinerea on tomato plants by the use of epiphytic yeasts Candida guilliermondii strains 101 and US 7 and Candida oleophila strain I182: II. a study on mode of action. Biological Control 25: 151-161.

Samson RA, Hoekstra ES, Van Oorschot CAN. 1984. Introduction to food-borne fungi. 2nd edition. Centraalbureau Voor Schimmelcultures, BAARN. Institute of the Royal Netherlands, Academy Arts Sci. pp. 248.

Stein T. 2005. Bacillus subtilis antibiotics: structures, syntheses and specific functions. Molecular microbiology 56: 845-857.

Sturz AV, Christie BR \& Matheson BG. 1998. Association of bacterial endophyte populations from red clover and potato crops with potential for beneficial allelopathy. Canadian Journal of Microbiology 44: 162-167.

Sutton JC. 1995. Evaluation of micro-organisms for biocontrol: Botrytis cinerea and strawberry, a case study. In: Advances in Plant Pathology, eds. J. H. Andrews, and I. C. Tommerup, Academic Press, San Diego, USA.

Toure $\mathrm{Y}$, Ongena $\mathrm{M}$, Jacques $\mathrm{P}$, Guiro A \& Thonart $\mathrm{P}$. 2004. Role of lipopeptides produced by Bacillus subtilis GA1 in the reduction of grey mould disease caused by Botrytis cinerea on apple. Journal of Applied Microbiology 96: 1151-1160.

Walker AS, Micoud A, Rémuson F, Grosman J, Gredt M \& Leroux P. 2013. French vineyards provide information that opens ways for effective resistance management of Botrytis cinerea (grey mould). Pest Management Science 69: 667-678.

Walker R, Innes CMJ \& Allan EJ. 2001. The potential biocontrol agent Pseudomonas antimicrobica inhibits germination of conidia and outgrowth of Botrytis cinerea. Letters in Applied Microbiology 32: 346-348.

Wisniewski ME \& Wilson CL. 1992. Biological control of postharvest diseases of fruits and vegetables: recent advances. HortScience 27: 94-98.

Wu L, Wu H, Chen L, Yu X, Borriss R \& Gao X. 2015. Difficidin and bacilysin from Bacillus amyloliquefaciens FZB42 have antibacterial activity against Xanthomonas oryzae rice pathogens. Scientific Reports 5: 12975.

Zhang Z, Jiang W, Jian Q, Song W, Zheng Z, Wang D \& Liu X. 2015. Residues and dissipation kinetics of triazole fungicides difenoconazole and propiconazole in wheat and soil in Chinese fields. Food Chemistry. 168: 396-403.

Zouari I, Jlaiel L, Tounsi S \& Trigui M. 2016. Biocontrol activity of the endophytic Bacillus amyloliquefaciensstrain CEIZ-11 against Pythium aphanidermatum and purification of its bioactive compounds. Biological Control 100: 54-62. 